\title{
ANALISIS PENGGUNAAN DANA TATA KELOLA DESA (STUDI KASUS DI KECAMATAN IV NAGARI BAYANG UTARA KABUPATEN PESISIR SELATAN)
}

\author{
Miftahul Fikri Iasra \\ Email: miftahullintan18@gmail.com \\ Jurusan Pembangunan Wilayah Pedesaan Pascasarjana Universitas Andalas Padang \\ J1. Limau Manis Kec. Pauh, Kota Padang \\ Erwin \\ Email: Erwin@gmail.com \\ Jurusan Pembangunan Wilayah Pedesaan Pascasarjana Universitas Andalas Padang \\ Jl. Limau Manis Kec. Pauh, Kota Padang \\ Wahyuni Syarfi \\ Email: Wahyuni Syarfi@gmail.com \\ Jurusan Pembangunan Wilayah Pedesaan Pascasarjana Universitas Andalas Padang \\ J1. Limau Manis Kec. Pauh, Kota Padang
}

\begin{abstract}
ABSTRAK
Tujuan penelitian adalah untuk mendeskripsikan dana Desa dari segi aspek, khususnya 1) Partisipasi. 2) Transparansi. 3) Akuntabilitas. 4) Efektivitas. Penelitian ini dilakukan di 6 Nagari di Kecamatan IV Nagari Bayang Utara Kabupaten Pesisir Selatan. Jenis-jenis catatan yang diperoleh dalam pembelajaran ini diambil dari dua sumber, terutama informasi fundamental dan data sekunder. Teknik analisis data yang diperoleh dalam mencari tahu dianalisis dengan menggunakan analisis evaluasi fakta kualitatif. Hasil penelitian yang telah dilakukan dapat dibuktikan dari 1) Penerapan transparansi oleh pemerintah nagari cukup baik dalam Pengelolaan Dana Desa. 2) Implementasi Akuntabilitas dalam Pemerintahan Penggunaan dana Desa oleh pemerintah desa cukup baik. 3) Pelaksanaan partisipasi pemerintah desa yang ada belum maksimal pada saat adanya Undangan Nagari Musrembang untuk menentukan arah pengembangan nagari dalam penggunaan dana desa, belum $100 \%$ tetapi baru menyentuh $\mathbf{7 1 , 4 \%}$ masyarakat yang hadir di musrembang nagari. 4) Penerapan efektifitas pengelolaan dana desa yang dilakukan oleh pemerintah desa di Kecamatan IV Nagari Bayang Utara Kabupaten Pesisir Selatan telah melaksanakan efisiensi dan penghematan dalam penggunaan dana dan alokasi dana lebih berorientasi pada kepentingan masyarakat.
\end{abstract}

Kata kunci: Tata Kelola. Dana Desa

\section{ABSTRACT}

The purpose of the study is to describe of Village Funds in terms of aspects, in particular 1) Participation. 2) Transparency. 3) Accountability. 4) Effectiveness. This research was conducted in 6 Nagari in District IV Nagari Bayang Utara, Pesisir Selatan Regency. The types of notes obtained in this study were taken from two sources, mainly fundamental information and secondary data. The data analysis technique obtained in finding out was analyzed using qualitative fact evaluation analysis. The results of the research that have been carried out can be proven from 1) The implementation of transparency by the nagari government is quite good in Village Fund Management. 2) Implementation of Accountability in Government The use of Village funds by the village government is quite good. 3) The implementation of existing village government participation has not been maximized at the time of the Nagari Musrembang invitation to determine the direction of nagari development in the use of village funds, not yet $100 \%$ but only touching $71.4 \%$ of the people who attend the Nagari Musrembang. 4) The implementation of the effectiveness of village fund management carried out by the village government in District IV Nagari Bayang Utara, Pesisir Selatan Regency has implemented efficiency and savings in the use of funds and the allocation of funds is more oriented to the interests of the community.

Keywords: Governance. Village Fund 


\section{Jurnal Ekonomi Pembangunan Vol. 7, No.1 (2021) 68-76}

\section{PENDAHULUAN}

Kehidupan hukum formal desa diakui dalam Undang-Undang Nomor 47 tahun 2015 tentang Pemerintahan Desa. Desa adalah satuan kegiatan masyarakat yang disetujui untuk menyelenggarakan dan mengurus urusan pemerintahan untuk kepentingan masyarakat lingkungan berdasarkan prakarsa lingkungan, hak ulayat, dan nama lain. Desa adalah kesatuan masyarakat hukum yang diberi wewenang untuk mengurus dan menyelenggarakan urusan pemerintahan untuk kepentingan lingkungan sekitar berdasarkan prakarsa masyarakat, hak-hak dasar, dan nama-nama lain. Undang-Undang Nomor empat puluh tujuh tahun 2015 pasal 34 ayat 2 tentang Pelimpahan kewenangan Desa sebagaimana dimaksud pada ayat (1), menteri yang menyelenggarakan urusan pemerintahan di luar bidang pemerintahan daerah berkoordinasi dengan menteri yang menyelenggarakan urusan pemerintahan di bidang dari pemerintah. pembangunan desa, pembangunan lingkungan desa, dan pemberdayaan masyarakat desa (Soekanto, 1982)

Meskipun keduanya diperuntukkan bagi desa dan merupakan penyuplai pendapatan desa (Pasal 72 ayat (1) Undang-Undang Nomor 6 Tahun 2014 tentang Desa), namun pembagian uang desa dan uang desa tidaklah sama. Sebagai informasi, dan seperti dikutip dari 'buku' Kementerian Desa, Daerah Tertinggal, dan Telekomunikasi 'Dana Desa Untuk Membangun Indonesia (Tanya Jawab Dana Desa)' Transmigrasi (Kemendesa). Dana desa bersumber dari Anggaran Pendapatan dan Belanja Negara (APBN) dan digunakan untuk membantu desa. Setiap 12 bulan desa menerima dana desa dari pemerintah pusat yang disalurkan melalui kabupaten/daerah. Uang desa diamanatkan oleh Undang-Undang Nomor 6 Tahun 2014 tentang Desa. Uang desa dialokasikan dalam struktur transfer, sekarang bukan proyek Uang desa akan terus disalurkan melalui Pemerintah Pusat selama Undang-Undang Nomor 6 Tahun 2014. Setiap tahun, uang desa disalurkan melalui APBD Kabupaten/Kota untuk memandu pelaksanaan kewenangan desa secara total berdasarkan usulan hak desa skala lingkungan. dan kewenangan yang harus dilaksanakan setiap 12 bulan anggaran sebagaimana diamanatkan dalam Pasal 22 ayat (1) huruf b dan ayat. dua L dua Undang-Undang (UU) Nomor 6 Tahun 2014 tentang Desa.

Meskipun mekanisme desa transfer dana dilakukan melalui kabupaten / kota, semua dari mereka harus disalurkan ke desa tanpa mengurangi sama sekali. Rekening Kas Umum Daerah / Kas Daerah dan Rekening Kabupaten / Kota Timah (RKUD) hanya dipesan sebagai tempat 


\section{Jurnal Ekonomi Pembangunan Vol. 7, No.1 (2021) 68-76}

penyimpanan sementara dana desa yang disalurkan oleh Pemerintah Pusat. Besaran dana desa sepuluh persen (10\%) dari dan luar Transfer Daerah (atau lebih) yang dialokasikan dalam APBN secara berjenjang (Nawawi, 1992)

Tujuan ekonomi dari peningkatan produktivitas pedesaan adalah untuk mengurangi kemiskinan pedesaan, yang merupakan salah satu tujuan pertumbuhan desa Kedua, tujuan sosial bertujuan untuk memastikan bahwa kesejahteraan penduduk desa terdistribusi secara merata Ketiga, prioritas budaya yang bertujuan untuk meningkatkan kualitas secara keseluruhan kehidupan di daerah pedesaan. Keempat, sasaran kebijakan adalah meningkatkan dan meningkatkan keterlibatan masyarakat pedesaan dalam kegiatan pembangunan serta pemanfaatan dan pengembangan hasil pembangunan (Nurman, 2015)

Besarnya alokasi dana desa sama dengan dana desa yaitu 10 persen (10\%). Namun, alokasi kas desa berasal dari DBH dan DAU yang dialokasikan dalam Anggaran Pendapatan dan Belanja Daerah (APBD) Kabupaten/Kota. Alokasi dana desa untuk setiap desa dan taktik penggunaannya diatur melalui Bupati/Walikota setiap tahun. Penggunaan uang desa sepenuhnya berdasarkan Pasal 25 Peraturan Menteri Keuangan Nomor 247 Tahun 2015 yaitu: Dana Desa diprioritaskan untuk pembiayaan peningkatan dan pemberdayaan masyarakat yang pelaksanaannya diprioritaskan melalui swakelola pemanfaatan lingkungan bahan baku/sumber, dan berusaha lebih banyak menyerap tenaga kerja dari masyarakat sekitar. Desa sebagai entitas badan usaha dagang yang secara politis memiliki kewenangan yang pasti untuk mengatur dan mengubah warganya atau masyarakatnya. Dengan fungsi tersebut, desa memiliki peran yang sangat esensial dalam membantu keberhasilan para penguasa dan kemajuan negara secara luas. Desa berada di garda terdepan dalam mencapai keberhasilan dalam segala hal dan penerapan kewenangan.

Menurut Undang-Undang Nomor 6 Tahun 2014 tentang Desa mengamanatkan agar keuntungan desa dalam DD tidak hanya berasal dari pendapatan desa yang unik tetapi juga dari alokasi Anggaran Pendapatan dan Belanja Negara (APBN), bagian dari dampak kabupaten/kota. pajak dan retribusi serta Alokasi Dana Desa. (DD) yang merupakan bagian dari dana perimbangan yang diterima melalui Kabupaten/Kota. Banyaknya alokasi dana secara langsung kedesa ditetapkan 10 persen dan di belakang dana alih daerah. seterusnya dibagi ke setiap desa dengan menggunakan pemikiran banyak penduduk, tingkat kemiskinan, luas wilayah, dan 


\section{Jurnal Ekonomi Pembangunan Vol. 7, No.1 (2021) 68-76}

tingkat masalah geografis. Dengan demikian, desa memiliki kewenangan untuk mengubah dan mengurus rumah tangga pribadinya, yang melibatkan peran pemerintah sebagai perusahaan penyedia publik dalam teknik perencanaan dan pelaksanaan pembangunan daerah yang melibatkan lingkungan di tingkat desa, hal ini diatur dalam Permendagri Nomor 20 Tahun 2018 tentang Pedoman Pengelolaan Dana Desa dalam Bab 1 Bagian Kedua Pasal 2 menjelaskan bahwa pengelolaan ekonomi desa dikelola secara terbuka, partisipatif, akuntabel dilaksanakan secara tertib.

Peraturan pemerintah berorientasi pada kepentingan umum. Menurut Sinambela, (2008) menyatakan bahwa pengelolaan kebijakan publik yang berkualitas adalah tingginya intensitas partisipasi masyarakat. Karena validitas setiap kebijakan publik dari pemerintah terletak di sana. Dialog dengan publik merupakan kebenaran suatu kebijakan dan menjadi wahana utama kebijakan yang siap digunakan. Pelaksanaan pemerintahan desa, perlu adanya kebijakan yang ditetapkan oleh kepala desa untuk mencapai tujuan pembangunan desa, rangkaian tindakan yang mempunyai tujuan tertentu yang diikuti dan dilaksanakan oleh aktor terpilih memiliki arti penting dalam mempengaruhi sejumlah orang

Menurut (Mardiasmo, 2009) partisipasi adalah keterlibatan masyarakat dalam pengambilan keputusan, baik secara langsung maupun tidak langsung melalui lembaga perwakilan yang dapat menyalurkan aspirasinya. Partisipasi tersebut dibangun atas dasar kebebasan berafiliasi dan berbicara serta partisipasi konstruktif. Partisipasi masyarakat adalah keterlibatan seorang laki-laki atau perempuan atau tim (masyarakat) yang secara aktif memberikan kontribusi secara sukarela terhadap suatu program pembangunan, seperti khawatir dalam perencanaan, pelaksanaan, pemantauan dan kontras.

Berdasarkan Pasal 79 ayat (1) UU No. 6 Tahun 2014 mengatur bahwa perangkat desa menyusun tata ruang perbaikan desa sesuai dengan kewenangannya dengan mengacu pada rencana pembangunan kabupaten/kota. Ketentuan terkait perencanaan perbaikan desa diatur lebih lanjut dalam Pasal 4 sampai dengan Pasal 51 Peraturan Menteri Dalam Negeri Nomor 114 Tahun 2014 tentang Pedoman Pembangunan Desa. Salah satu faktor penentu keberhasilan upaya di atas adalah partisipasi masyarakat dalam proses perbaikan desa secara keseluruhan. Ia menempatkannya pada partisipasi masyarakat karena: pertama, masyarakat pedesaan lebih mengenal apa yang mereka inginkan dan inginkan. Kedua, masyarakat desa lebih mengenal 


\section{Jurnal Ekonomi Pembangunan Vol. 7, No.1 (2021) 68-76}

kondisi desa, masing-masing ketentuan jamu (lingkungan fisik dan fenomena alam) dan sosial. Ketiga, pengalaman tugas kelurahan terhadap pelaksanaan dan akibat pembangunan desa mulai dari perencanaan, pengambilan pilihan, pelaksanaan hingga evaluasi. Perbaikan desa perlu didukung melalui dana yang tersedia. Pendanaan merupakan unsur yang paling menentukan dalam pelaksanaan pembangunan pemikiran dari masyarakat. Pada tahun 2000, Pemerintah mengaitkan kebijakan Dana (Anwas, 2013)

\section{METODE PENELITIAN}

Penelitian ini dilakukan di 6 Nagari yaitu, Nagari Puluik-Puluik, Kota Ranah, Muaro Aie, Pancuang Taba, Puluik-Puluik Selatan dan Limes Gadang Pancuang Taba di Kecamatan IV Nagari Bayang Utara Kabupaten Pesisir Selatan. Saat Penelitian Analisis Tata Kelola Penggunaan Dana Desa di Kecamatan IV Nagari Bayang Utara dilaksanakan selama 3 bulan, yaitu dari Juni 2019 hingga September 2019. Jenis data yang dikumpulkan dalam penelitian ini diambil dari dua sumber, yaitu data primer dan data sekunder. Teknik pengumpulan data dilakukan dengan teknik observasi, wawancara dan dokumentasi. Teknik analisis data yang diperoleh dalam penelitian dianalisis dengan menggunakan analisis data kualitatif (Moleong, 2002)

\section{HASIL DAN DISKUSI}

Kecamatan IV Nagari Bayang Utara terdiri dari 6 desa yaitu Puluik-Puluik, PuluikPuluik Selatan, Muaro aie, Pancuang Taba, Limau Gadang. Kepadatan penduduk di Kecamatan IV Nagari Bayang Utara 7.277 jiwa terdiri dari 3.475 laki-laki dan 3.802 perempuan. Panjang jalan di Kecamatan Bayang Utara hingga akhir tahun 2017 tercatat sepanjang 135 Km, terdiri dari jalan aspal $49 \mathrm{Km}$, jalan diperkeras $35 \mathrm{Km}$ dan jalan tanah $51 \mathrm{Km}$. Sedangkan jumlah jembatan di Kecamatan Bayang Utara sekitar 20 buah. Keberhasilan pelaksanaan tugas pokok dan fungsi Kantor Bupati Nagari Bayang Utara dikelola oleh sumber daya manusia yang ada didalamnya. Selain itu, keberhasilan juga akan sangat ditentukan dengan menggunakan Rencana Kerja dengan memperhatikan semua dukungan dari cukup banyak sumber daya organisasi dan lingkungan organisasi, interaksi dari berbagai sumber tersebut pada akhirnya akan menentukan perumusan teknik dan target kinerja. Dengan kata lain, melalui rencana kerja akan diketahui sejauh mana kinerja secara keseluruhan telah dijalankan dalam menjalankan tugas pokok dan fungsinya. Rencana Kerja Kecamatan IV Nagari Bayang Utara Kabupaten Pesisir Selatan 


\section{Jurnal Ekonomi Pembangunan Vol. 7, No.1 (2021) 68-76}

dimaksudkan untuk menentukan strategi yang tepat untuk mencapai maksud dan tujuan dalam penyelenggaraan pemerintahan, penyelenggaraan pembangunan dan pelayanan kepada masyarakat berdasarkan asas-asas pemerintahan yang baik.

Dari laporan Rekapitulasi Penyaluran Dana Desa di Desa / Nagari Kabupaten IV Nagari Bayang Utara Tahun Anggaran 2017-2018 dijelaskan bahwa dana desa untuk masing-masing nagari berbeda pada tahun 2017 terdapat nagari yang memperoleh dana desa paling rendah Desa Nagari / Koto Ranah 773.118.838 dan yang tertinggi adalah Nagari atau Deasa Pancuang taba 906.875.048 dan total Dana Desa di kecamatan pada tahun 2017 adalah 4.823.193.053 sedangkan untuk dana desa tahun 2018 desa yang paling banyak menerima dana desa yaitu desa Pancuang Taba dengan 1.122.066.000 dan desa yang menerima dana desa paling sedikit adalah Desa Muaro Aie yang menerima dana desa 735.921.000 dan total Dana Desa di kecamatan pada tahun 2018 adalah 5.524.668.000

Pemanfaatan dan penyajian realisasi desa terbesar pada tahun 2017 terdapat di desa ranah Koto dimana realisasi desa $100 \%$ dan realisasi desa terendah adalah desa Muaro Aie yaitu 96,62 persen dan rata-rata realisasi desa di kecamatan pada tahun 2017 sebesar 99,3\%. Sedangkan penyajian realisasi penggunaan dan desa terbesar tahun 2018 adalah Desa PuluikPuluik, realisasi desa sebesar 98,0\% dan realisasi desa terendah yaitu 87,7\% dan rata-rata realisasi desa di kecamatan pada tahun 2017 yaitu $94 \%$

Alokasi uang desa setiap tahun terus meningkat pada tahun 2017 dari 4.823.193.053 pada tahun 2018 menjadi 5.524.668.000 sedangkan kesadaran penggunaan uang desa menurun pada tahun 2017 sebesar 99,3\%, turun pada tahun 2018 menjadi 94\%. Uang desa merupakan salah satu sumber pendapatan desa yang penggunaannya terintegrasi dengan Anggaran Pendapatan dan Belanja Negara (APBNag). Oleh karena itu, perencanaan permohonan dan halhal yang harus dilakukan diatur melalui Musyawarah Perencanaan Pembangunan Desa (Musrenbangdes). MusrenbangNag merupakan wadah diskusi untuk pengusulan rencana pembangunan di tingkat desa yang berpedoman pada prinsip-prinsip Perencanaan Pembangunan Partisipasi Masyarakat (P3MNag) Nagari. Sila ini menuntut keterlibatan masyarakat dalam pengambilan keputusan dan kemauan perbaikan yang akan dilakukan, khususnya yang ada di nagari terkait, agar mereka pada kenyataannya menjawab keinginan/aspirasi yang berkembang.

Sistem partisipasi lingkungan dilakukan dalam rangka menerapkan prinsip partisipasi 


\section{Jurnal Ekonomi Pembangunan Vol. 7, No.1 (2021) 68-76}

atas keinginan masyarakat sehingga masyarakat merasa lebih berkembang. Dengan demikian secara bertahap lingkungan akan terpenuhi sebagai masalah pembangunan. Ajaran partisipasi ((Hempri, 2003) adalah pelibatan setiap warga negara dalam pengambilan keputusan baik tanpa ditunda-tunda maupun melalui lembaga-lembaga yang sesuai dengan kepentingannya. Oleh karena itu, untuk mengimplementasikan derajat partisipasi masyarakat pedesaan harus dimulai dari konsep pemberdayaan dimana sistem pemberdayaan terdiri dari dua kecenderungan, yaitu; Pertama: cara pemberdayaan yang menekankan pada cara memberi dan mengalihkan suatu daya, kekuatan, atau kemampuan kepada masyarakat agar menjadi lebih berdaya. Kedua: menekankan pada proses merangsang, mendorong atau memotivasi manusia untuk memiliki kemampuan atau pemberdayaan atau membuat pilihan melalui proses berkomunikasi. Pelaksanaan aplikasi dana desa di Kecamatan IV Nagari Bayang Utara Kabupaten Pesisir Selatan juga dilakukan dalam rangka pemberdayaan masyarakat dan menitikberatkan pada motivasi untuk berpartisipasi dalam pembangunan desa. Kegunaan sila partisipasi juga dibuktikan melalui hasil wawancara: "Sebagian besar kontributor LPM Nagari ikut serta dalam musyawarah desa terkait pembangunan. Selain agar bisa kita kaji bersama-sama dengan aparat kecamatan dan nagari, juga agar kita bisa ikut menentukan pembangunan apa yang akan dilakukan di desa tersebut."

Jika dilihat dari partisipasi dalam hal pengambilan keputusan penggunaan dana dapat dikatakan bahwa partisipasi masyarakat cukup baik. Hal ini dibuktikan dengan data sampel tingkat kehadiran masyarakat di Kecamatan dan Musrembang Musyawarah Nagari di 6 (enam) desa / nagari di wilayah Nagari, Kecamatan IV Nagari Bayang Utara yaitu Puluik-Puluik, Puluik-Puluik Selatan, Muaro aie, Kota Ranah, Pancuang taba, Limes gadang sebagai berikut. Tabel 1 Secara keseluruhan rata-rata persentase kehadiran dan kehadiran masyarakat di Kabupaten Musrembang dan Musrembang tingkat 6 Nagari adalah sebagai berikut:

\begin{tabular}{|c|l|c|c|c|}
\hline \multirow{2}{*}{ No } & \multirow{2}{*}{ Musrembang } & Jumlah & Jumlah & \multirow{2}{*}{$\%$} \\
\cline { 3 - 4 } & & Undangan & Persen & \\
\hline 1 & Kecamtan & 294 & 235 & 79,93 \\
\hline 2 & Nagari Puluik-Puluik Selatan & 57 & 45 & 78,95 \\
\hline 3 & Nagari Limau Gadang & 51 & 34 & 66,67 \\
\hline 4 & Nagari Muaro Aie & 46 & 34 & 73,91 \\
\hline 5 & Nagari Pancuang Taba & 71 & 50 & 70,42 \\
\hline 6 & Nagari Koto Ranah & 69 & 58 & 84,06 \\
\hline 7 & Nagari Puluik-Puluik & 77 & 57 & 74,03 \\
\hline
\end{tabular}




\section{Jurnal Ekonomi Pembangunan Vol. 7, No.1 (2021) 68-76}

\begin{tabular}{|c|c|c|c|c|}
\hline & Jumlah & 665 & 513 & 71.4 \\
\hline
\end{tabular}

Dari data tersebut, tingkat partisipasi (kehadiran) dalam pengambilan keputusan masih sangat tinggi, di atas 71,4\%. Hal ini menunjukkan bahwa kesadaran/derajat fokus publik dalam musyawarah kabupaten dan musrembang nagari di 6 (enam) desa/nagari di wilayah Nagari, Kecamatan IV Nagari Bayang Utara khususnya Puluik-Puluik, Puluik-Puluik Selatan, Muaro Aie, Pancuang Taba Wilayah Kota, Kecamatan Limau Gadang IV Nagari Bayang Utara dalam mengambil peran aktif dalam pengelolaan perbaikan ikhlas cukup tinggi. Padahal tak terhitung banyaknya tokoh masyarakat yang datang semata-mata untuk memenuhi undangan rapat desa. Namun, kehadiran ini dapat membantu tugas pemerintah untuk mengenali kebutuhan lingkungan, menempatkan agenda dan prioritas layanan, dan membuat program pembawa sesuai dengan keinginan dan aspirasi lingkungan (Ferdinand, 2005)

Sebagai perangkat lunak atau kegiatan siklus tahunan, dana desa dilakukan setiap tahun. Oleh karena itu, proses pelaksanaan dana desa mulai dari perencanaan, pelaksanaan hingga pemantauan dan kontras juga dilakukan setiap tahun. Berkaitan dengan hal tersebut, ada tokoh masyarakat yang mengaku selalu mengikuti teknik perencanaan dana desa tetapi sematamata mengikutinya untuk memberikan semangat dan motivasi kepada anggota masyarakat lainnya (Sulistyani, 2004).

\section{KESIMPULAN DAN SARAN}

Berdasarkan hasil dan pemulungan dari penelitian yang telah dilakukan dapat disimpulkan: 1) Penerapan transparansi yang dilakukan oleh pemerintah nagari di Kecamatan IV Nagari Bayang Utara Kabupaten Pesisit Selatan cukup baik dalam Pengelolaan Dana Desa. Namun demikian, masih terdapat beberapa indikator transparansi yang belum diterapkan secara maksimal, seperti salah satu Nagari Limau gadang yang belum menjelaskan penggunaan dana desa kepada masyarakat. 2) Implementasi Akuntabilitas dalam Pemerintahan Penggunaan dana Desa oleh pemerintah desa di Kecamatan IV Nagari Bayang Utara Kabupaten Pesisit Selatan sudah cukup baik. Namun masih terdapat beberapa indikator akuntabilitas yang belum diterapkan secara maksimal, ada beberapa nagari yang belum melaksanakan Verifikasi SPP di Kecamatan dalam penghimpunan dana desa, padahal Verifikasi SPP di kecamatan menjadi salah satu syaratnya. dalam penarikan dana desa sebagaimana tertuang dalam Peraturan Bupati 


\section{Jurnal Ekonomi Pembangunan Vol. 7, No.1 (2021) 68-76}

Nomor 9 Tahun 2015. 3) Pelaksanaan partisipasi pemerintah desa di Kecamatan IV Nagari Bayang Utara Kabupaten Pesisit Selatan masih belum optimal, dalam penyelenggaraan pemerintahan desa dana karena partisipasi aktif masyarakat yang hadir pada ajakan nagari musrembang untuk menentukan arah pembangunan desa dalam penggunaan dana desa tidak $100 \%$ tetapi hanya menyentuh $71,4 \%$ masyarakat yang hadir pada musrembang nagari. 4) Penerapan efektifitas pengelolaan dana desa yang dilakukan oleh pemerintah desa di Kecamatan IV Nagari Bayang Utara Kabupaten Pesisir Selatan telah melaksanakan efisiensi dan penghematan dalam penggunaan dana dan alokasi dana lebih berorientasi pada kepentingan masyarakat. sehingga pengabdian masyarakat desa dikatakan baik. Dari kesimpulan diatas dapat dikatakan bahwa pengelolaan dana desa di Kecamatan IV Nagari Bayang Utara Pesisir Selatan sudah cukup baik dengan menerapkan prinsip dan aturan mengenai efektivitas. Namun untuk asas transparansi, akuntabilitas dan partisipasi dalam pengelolaan dana desa belum dilakukan secara maksimal baik di sisi pemerintahan desa maupun dari sisi masyarakat.

\section{DAFTAR PUSTAKA}

Anwas. (2013). Pemberdayaan Masyarakat Era Globalisasi. Alfabeta.

Ferdinand. (2005). Metode Penelitian Manajemen: Pedoman Penelitian Untu Skripsi, Tesis Dan Disertasi Ilmu Manajemen. Semarang: Universitas Diponegoro. Universitas Diponegoro.

Hempri, S. \&. (2003). Pengembangan Masyarakat dari Pembagunan Sampai Pemberdayaan. Aditya Media.

Mardiasmo. (2009). Akutansi Sektor Publik. Yogyakarta.

Moleong, L. J. (2002). Metodologi Penelitian Kualitatif. Remaja Rosdakarya.

Nawawi, H. dan M. M. H. (1992). Instrument Penelitian Bidang Sosial. Yogyakarta: Gadjah Mada University Press. Gadjah Mada University.

Nurman. (2015). Strategi Pembangunan Daerah. Rajawali Pers.

Sinambela, L. P. (2008). Reformasi Pelayanan Publik. Rineka Cipta.

Soekanto, S. (1982). Sosiologi Suatu Pengantar. Rajawali Pres.

Peraturan Menteri Dalam Negeri Nomor 690.900-327 tahun 1996 tentang Kriteria Penilaian dan Kinerja Keuangan. Jakarta

Sulistyani, A. T. (2004). Kemitraan dan Model-Model Pembelajaran. Gava Media. 